\title{
EXECUTIVE ORDER 13223 \\ WE DARE NOT ALLOW OURSELVES TO BE BUSH-WHACKED ${ }^{1}$
}

THANK YOU FOR INVITING ME to be here with you this evening. It is a privilege to sit with the members of this panel who have been fighting "the good fight" on behalf of access to presidential records for so long. I was particularly interested in the comments of John Brademas, to whom we all owe so much for his role over the years in promoting openness to government records. Tonight, I wish to focus my comments on the ongoing effort to overturn President George Bush's Executive Order 13223. I will begin with some background that explains my own involvement in this controversy, then trace the efforts in Congress and in the courts to overturn this offensive order, and finally offer a call for eternal vigilance from all of us in the historical and the archival communities.

Historians generally are reluctant to assess the performance of current political leaders. This seems to be a task best left to political scientists. Usually, members of our profession take advantage of the benefits that accrue from historical perspective before rendering profound pronouncements. After years of reflection, however, both historians and political scientists generally agree that each president has a set of central issues that seems to define his administration. For Ronald

1. Dr. Craig initially prepared these remarks for the symposium at New York University on February 26, 2002. He subsequently expanded and updated the commentary in August 2002 to reflect more recent developments. 
Reagan, tax cuts and the reduction of big government proved definitive. For Bill Clinton, the character question cast a long shadow over his presidency. George W. Bush thus far appears preoccupied with making his self-declared, but unsanctioned, war on terrorism his signature issue. Still, in the final analysis, I have little doubt that one key element will ultimately define, or perhaps more accurately corrupt, his presidency: "secrecy."

As seasoned Hill-watchers, my colleagues and I typically deal with secrecy-related issues each time a new administration assumes power. Executive uneasiness usually focuses on such issues as national security and foreign affairs. In George Bush's case, however, security concerns transcend these traditional realms. From the day that he assumed office and declared an unwillingness to use electronic mail for fear of prompting a Freedom of Information Act (FOIA) request from some entrepreneurial reporter, the president has been overly concerned-and perhaps even paranoid-about government security. Officials in the Bush administration have repeatedly invoked claims of executive privilege where no obvious justification exists. In case after case, presidential claims of privilege repeatedly have been struck down by the courts. Still, with each new defeat, White House aides return to their desks and find more opportunities to try and stop information from flowing to historians, political scientists, and media reporters.

My position as director of the National Coordinating Committee for the Promotion of History (NCC), which will soon be renamed the National Coalition for History, requires me to wear two hats: the top hat of the historian and the cap of the journalist. When reporting on news of interest to the historical and archival communities through the NCC Washington Update, our weekly Internet publication, I strive for objectivity. I also lobby regularly on behalf of our profession's needs, however, and thereby occasionally assume controversial positions in 
order to help us assert our views and present our positions. This places me in close contact with the news media, and I remain ever vigilant for information that affects our community. I keep my eyes and ears open when tracking down rumors on Capitol Hill and, like any good lobbyist, receive interesting insider information. Several "moles" operating in various federal agencies and in the halls of Congress often provide useful advance information on stories and developments that affect our community.

It was an unusually quiet October day in my third floor office near the Library of Congress when I received a phone call from one of those agency sources. Contrary to accusations from the Bush White House, the source did not emanate from within the National Archives and Records Administration (NARA). My informant revealed that a draft presidential records order was in the process of being circulated to various federal agencies and that it possessed important implications for the Presidential Records Act (PRA). The stakes seemed high: the order potentially affected some 68,000 pages of papers reflecting confidential advice to the president during the Reagan administration. NARA had sought to open these documents to scholars in accordance with the law, and this order related directly to this release. Because the draft order contained no "eyes-only" or "confidential" stamp, my source felt at liberty to share it with me, and I planned to follow my standard procedure for reviewing such material: look it over, circulate it to contacts in the historical and archival professions, and construct a response. I awaited the fax from my source.

When the fax arrived a few minutes later, I could barely believe the contents. I quickly sent a copy to Professor Hugh Graham of Vanderbilt University, an eminent presidential scholar with a superb reputation and a long-standing interest in access to executive records. In a matter of minutes, he responded with this note: "From a quick reading, this is 
a real monster, far worse than the 1989 executive order it would replace. It appears to reverse the public access premise of the PRA after 12 years, replacing it with a requirement that any FOIA request by a researcher for documents bearing not just on national security issues, but broadly on the entire communications or deliberative process of the president or his advisors, first be justified by some undefined 'demonstrable, specific need' then win agreement by both the former and incumbent president, who are given unlimited time to ponder the matter... the Archivist [of the United States] becomes a kind of warden or guardian of official secrets... I am surprised by such broad overreaching by the Bush White House. They would reverse an act of Congress with an executive order."

Anna Nelson, the distinguished history professor at American University and former member of the John F. Kennedy Assassination Records Review Board, offered a similar observation. She feared that President Bush appeared to be establishing a precedent that would give him complete control over his own papers 12 years after he vacated the Oval Office. "This order sets up a minefield in front of what was a straightforward piece of legislation," Nelson exclaimed. Similar criticism arrived from Steven Aftergood of the Federation of American Scientists, Scott Nelson from the Public Citizen Litigation Group, and several other scholar/activists. All interested parties reached a universal consensus: the draft order needed to be challenged. In fact, the order appeared so egregious that we recognized the need to move beyond offering commentary and into an all-out effort to defeat the measure by providing immediate media exposure.

My own knowledge of the national press corps produced the conclusion that it might be best to "leak" this information to George Lardner 
Jr., a Washington Post staffer. It appeared to be an ideal topic for an interesting back-page story in an influential newspaper. Lardner conversed with me briefly, offered his thanks for the lead, and quickly launched his own investigation. The results appeared on page 33 of the November 1, 2001 edition of the Washington Post. The headline announced the substance of the story in bold black letters: "Bush Clamping Down on Presidential Papers." My suspicion that this appeared to be a slow news day was confirmed when Lardner's story constituted the focus of the White House's morning press briefing, commonly known within the journalistic community as the "morning gaggle." When questioned about the draft executive order, White House press secretary Ari Fleischer appeared taken by surprise. Clearly, he knew very little about the issue and immediately assumed a defensive posture, incorrectly asserting that the order was necessary for "national security" concerns. His performance proved especially embarrassing, and the White House hurriedly assembled a special press briefing later in the day. The Bush administration selected Alberto Gonzales, a White House counsel, to conduct this briefing and calm the waters.

Lardner's story, however, had broken open the floodgates. Deb Reichman of the Associated Press, along with several other news syndicates, quickly picked up on the issue. This translated into dozens of pieces in papers across the country, including The New York Times, the Chicago Tribune, and The Christian Science Monitor. Virtually every influential national newspaper offered some coverage. Soon afterward, the broadcast journalists followed suit and the White House entered into full "damage control" mode. I am not privy to any of the discussions that took place within the Bush White House at that point. Evidence suggests, however, that the president's policy advisors attempted to bury this press debacle as quickly as possible. The White House decided that Bush's most effective move might be to sign the order immediately so that the issue could be concluded and they would 
not need to go through another "bad press day" down the road. On November 1, Bush signed the executive order.

Still, the White House's broader strategy failed. News stories continued to appear, supplemented by stinging editorial commentary. Such headlines as "Presidential Records Put Under Gag Order," "A Dark Oval Office," and "A Flawed Approach to Records" peppered the popular media. Growing numbers of journalists, editorial writers, historians, and concerned citizens began to ask uncomfortable questions. What could possibly be contained in those presidential records that so concerned George Bush? What was he hiding ? $^{3}$

In fact, nothing in the records could or should have raised major concerns within the White House. In July 2002, some 20 months after the records should have been released, the Bush administration finally cleared all disputed 68,000 Reagan-era records. This did not completely resolve the issue. As of this writing (August 2002), despite the release of the records, the draconian executive order still stands. We can take comfort in the fact that it is not going unchallenged. One coalition of historical, archival, and media organizations has brought suit in federal court. In addition, a bipartisan coalition of concerned members in Congress continues their brave and bold efforts to overturn and nullify the offensive executive order.

The opening of the Reagan records may have alleviated some concerns, but greater problems remain. Bush set into motion a dangerous precedent for the present and future release of presidential records when he signed Executive Order 13233. I personally feel that Bush could have

3. For examples of critical press coverage, see the following: Los Angeles Times, 6 November 2001; San Francisco Chronicle, 11 November 2001, http://www.sfgate.com/cgi-bin/article.cgi?f=/c/a/2001/ 11/11/ED81976.DTL; Christian Science Monitor, 14 November 2001; The New York Times, 15 November 2001, http://www.nytimes.com/2001/11/15/opinion/15THU4.html; op-ed by historian Richard Reeves in The New York Times, op-ed page, http://www.nytimes.com/2001/11/16/opinion/ 16REEV.html. 
cared less about the concerns over this executive order as expressed by the historical and archival communities. He clearly fretted, however, about a continual barrage of unfavorable attention in the nation's media outlets. To avoid additional criticism, Bush hastily and unwisely took the advice of his counselors and signed the executive order. This poorly prepared and ill-conceived document proved blatantly unconstitutional in many of its provisions. I remain completely confident that this order, similar to Bush's other claims of executive privilege, will be struck down by the courts or Congress, if not both.

I would like to turn briefly now to consider the specifics of the legislation and to outline the ways in which politicians and public-interest advocates have challenged its substance. When George Bush issued Executive Order 13233, entitled "Further Implementation of the Presidential Records Act," he effectively overruled Ronald Reagan's Executive Order 12667 issued on January 18, 1989, and essentially reinterpreted the Presidential Records Act of 1978. Bush's new order allows a sitting president to keep secret the papers of a previous president, even if that previous president desires to have his papers open to public scrutiny. In effect, this new order provides for the release of certain types of presidential papers only when the former and sitting presidents both agree to release the papers. The order reverses the very premise of public access that had been built into the PRA, which provides for the systematic release of presidential records either after 12 years or by virtue of a successful FOIA request. The new executive order requires that materials should be released only when a FOIA request shows a "demonstrable, specific need." 4

Administration officials have argued that the new executive order had been intended merely to provide an "orderly process" for the release of 
presidential papers. During the testy press briefing on November 1, for example, Ari Fleischer stated that the order was designed to provide a "safety valve" for any current administration. He based this on the theory that a former president, out of office for 12 years, might not recognize the national security implications of releasing certain documents. During a brief question-and-answer session in the Rose Garden the following day, after the president signed the executive order, Bush stated his belief that "it's a process that I think will enable historians to do their jobs" and at the same time protect state secrets. ${ }^{5}$

Historians familiar with the provisions of the original Presidential Records Act disagreed then, as they do now. Hugh Graham characterized the White House spokespersons' explanations as "absurd," since national security records already enjoyed protection from release. Historians were not alone in expressing their concern. Bruce Lindsey, a former deputy White House counsel under Bill Clinton and currently a lawyer for the William J. Clinton Foundation, wrote a letter voicing his displeasure. Lindsey observed that "a government's legitimacy is based on the trust of its people... when decisions are made on behalf of the American people, citizens eventually have to be able to see the process of how those decisions came to be."

Rhetoric alone, however, could not move the issue forward. As a practical matter, executive order opponents opened two fronts in the campaign to challenge 13233: one in Congress and another in the courts. Representative Stephen Horn (R-CA), chair of the Subcommittee on Government Efficiency, Financial Management and Intergovernmental Relations of the House Committee on Government Reform, quickly emerged as a key player in Congress. Horn had planned to hold hearings concerning the White House's delay in releasing the 68,000 
pages of Reagan presidential papers several weeks prior to the signing of Bush's executive order, but committee work had been postponed several times owing to anthrax threats on Capitol Hill. Following the promulgation of 13233, however, Horn refocused his energies. He rescheduled his hearing for November 6 and broadened its scope to examine the totality of the Presidential Records Act of 1978. Witnesses included John Carlin, Archivist of the United States; Scott L. Nelson, attorney for the Public Citizen Litigation Group; Professor Mark J. Rozell of Catholic University; Professor Peter M. Shane of the University of Pittsburgh and Carnegie-Mellon University; and Anna Nelson of the American University, who also delivered testimony on behalf of the American Historical Association, the Organization of American Historians, and the Society of American Archivists. ${ }^{6}$

No Democrats attended the two-hour hearing, although Rep. Henry Waxman (D-CA), the ranking minority member, and Rep. Janice Schakowsky (D-ILL), a committee member, issued a joint statement calling on President Bush to rescind the order. Two congressmen representing the Republican majority did attend, including Chairman Horn. Although Horn fell short of calling on Bush to rescind the order, he did urge the administration to "revisit" this issue in order to remove the hurdles to public access. Rep. Doug Ose (R-CA), a committee member who expressed strong interest in obtaining the release of Clinton presidential documents, doggedly pressed administration witnesses for answers to specific issues and concerns throughout the proceedings. ${ }^{7}$

M. Edward Whelan III, acting assistant attorney general, represented the White House and clearly presented the administration's position.

6. The testimony of various witnesses may be found online at http://www.fas.org/sgp/congress/ 2001/index.html\#pra. The Society of American Archivists also sent a letter to Representative Horn expressing "grave concern" about the executive order. See http://www.archivists.org/news/ stephenhorn.html.

7. The November 6 letter from Waxman and Schakowsky to Bush can be found at http:// www.fas.org/sgp/news/2001/11/pra_let.html. 
He argued that the order merely establishes a "procedure" whereby presidents may invoke "constitutionally based privileges" in order to withhold documents that otherwise might be disclosed after a 12-year waiting period. Rep. Ose especially grilled Whelan, asserting that the new order "undercuts the public's right to be fully informed about how its government operated in the past." Ose demonstrated that the order imposed new requirements that had not been envisioned in the Presidential Records Act of 1978. In fact, the order established two new broad categories of documents that presidents might withhold: "communications" between the president and his advisors, and records containing "legal advice or legal work." Ose noted that the 1978 law only protected "confidential communications" between the president and his advisors and contained no reference to attorney-client privilege. The congressman appeared especially irked that Bush's executive order dropped the word "confidential" from "confidential communications" and argued that this policy change amounted to an illegal expansion of authority. Whelan responded that "there is no expansion. Therefore, there is no policy basis for an expansion."

Legal scholars testified that the order moved beyond both the current law and legal precedent by asserting executive privilege for vicepresidential records. One witness argued that this expansion contained no basis in law. With the sole exception of Whelan, all panelists expressed the concern that the order attempted to rewrite the PRA by requiring individuals to show a "demonstrated, specific need" to access materials through a FOIA request. The Presidential Records Act had mandated the systematic release of records through established archival procedures. John W. Carlin, found himself in an especially difficult position because the new order eviscerated his authority over presidential records and yet he remained responsible to the president as a member of the executive branch. He testified that the order would apply retroactively to all presidential record requests that awaited 
processing, including those concerning the 68,000 disputed documents from the Reagan administration.

Anna Nelson noted that the new order would undoubtedly "hamper the ability of the public to gain timely access to records." When questioned about the Reagan records, she observed that it hardly appeared unusual for former presidents and their staffs "to worry about the content of papers they no longer remember," but also cautioned the subcommittee that "secrecy breeds conspiracy theories." Consequently, she urged the opening of the Reagan papers as quickly as possible. By the time the hearing ended, two things had become clear. First, several national organizations contemplated legal challenges to open the historical records consistent with the provisions of the Presidential Records Act. Second, Rep. Horn intended to open a dialogue with administration officials in an effort to remove the hurdles to public access. Horn's staff informed me that the congressman would not hesitate to consider legislation that supplanted Bush's controversial decree, if necessary.

On April 11, 2002, Rep. Horn joined with more than a dozen House colleagues to introduce the Presidential Records Act Amendments of 2002 (H.R. 4187), designed to "fix a serious, but readily solvable, problem in the implementation of the Presidential Records Act of 1978," in the words of its sponsors. According to Horn, "the Presidential Records Act of 1978 was a landmark law. It declared for the first time that the official records of a former president belong to the American people and imposed 'an affirmative duty' on federal officials 'to make such records available to the public as rapidly and completely as possible consistent with the provisions of the Act.'" Horn's bill sought to preserve the constitutional rights of former and incumbent presidents to assert executive privilege. Unlike Executive Order 13233, however, it operates in a manner largely consistent with the 1978 legislation. 
Horn's bill requires the Archivist of the United States to provide an advance notice of 20 working days to former and incumbent presidents prior to releasing presidential records in accordance with the 1978 Act. The archivist would release the records upon the expiration of this 20day period, excepting any records or parts of records for which the president asserted a claim of privilege. The archivist could also extend the 20-day period for an additional 20 days if the former or incumbent president demonstrated a need for additional time to review the records, but this should be invoked only in rare circumstances. The former and incumbent presidents would have ready access to the records and could conduct their reviews well before the time in which the records appeared ready for public release. The archivist also would have thoroughly categorized and screened the records before issuing notice to the presidents, which should greatly facilitate their review.

Horn's bill also requires that any claim of privilege be made in writing and signed by the former or incumbent president, that the claim specify the applicable records, and that the nature and grounds of privilege should be delineated clearly. Notices of the proposed release of records, as well as any claims of privilege, would be made public. If the former president submitted a privilege claim, the archivist would withhold the records covered by that claim for another 20 working days. This would permit the former president to seek judicial enforcement of his privilege claim, as already provided for in the Presidential Records Act of 1978. After the expiration of this 20-day period, the archivist would release the records automatically unless a court ordered their continued withholding. This approach places the burden of establishing a privilege claim on the former president. Privilege claims for former presidents should prove extremely rare under this legislation, given the protections already built into the 1978 act and considering the age of the records. In the case of an incumbent president submitting a privilege claim, procedures would differ somewhat. The 
archivist would withhold the records unless and until either the incumbent president withdrew the claim or a court issued some final and nonappealable order directing the archivist to release the records. This approach recognizes the legal and practical reality that the archivist must honor a privilege claim by an incumbent president.

Horn's bill applies similar procedures to requests for access to records by Congress and the courts. Specific time periods, however, would be modified to ensure compliance with deadlines imposed by subpoenas or by other legal processes. The bill also does not specify any outcome if the incumbent president claimed privilege in response to a congressional or judicial access request. Disputes between incumbent presidents and either Congress or the courts would be resolved on a case-bycase basis. The bill also makes several conforming changes to existing provisions of the Presidential Records Act of 1978. It recognizes that the authority to claim executive privilege is personal to a former or incumbent president and cannot be delegated to representatives. This is consistent with both current legal theory and practice concerning executive privilege. The bill also underscores that a former or incumbent vice president cannot claim presidential executive privileges. Finally, and best of all from both an archivist's and an historian's viewpoint, the bill provides that Executive Order 13233 shall have no force or effect.

Congressman Horn hoped to move his bill rapidly through the House. He quickly called a second hearing for April 24, at which time subcommittee members heard testimony from several distinguished legal scholars. Panelists included Jonathan R. Turley, professor of law at George Washington University Law School; Morton Rosenberg, specialist in American public law at the Congressional Research Service; Mark J. Rozell, professor of politics at The Catholic University of America; and Todd Gaziano, director of the Center for Judicial and Legal Studies 
at the Heritage Foundation. One passing remark by Gaziano confirmed many historians' suspicions about the primary motivations of Bush's attorney/advisors within the Justice Department who crafted the executive order. "The careers and reputations of government officials often extend beyond 12 years and they are conscious of this," Gaziano observed. There appears little doubt that the Bush administration contains many future Henry Kissinger wannabes, some of whom last worked for Special Counsel Kenneth Starr and that they fear the advice they give President Bush today may haunt their careers at some future date. Ideally, these young policy-wonks would prefer to see the Presidential Records Act revised to keep their advisory records securely locked away for eternity or, failing that, for a minimum of 25 years.

Representative Dan Burton (R-IN), chair of the full Government Reform Committee, also made a dramatic appearance before Horn's 
subcommittee and lashed out at President Bush for signing Executive Order 13233. Burton remarked that "this executive order just goes too far. ... for the White House to block access to historical documents that Congress has a right to is just insane." Speaking plainly and directly, an animated Burton blamed Bush's Justice Department aides for giving the president "bad advice" about signing the executive order. He also expressed full support for H.R. 4187 and predicted that the measure would pass the full House. Burton further minced no words when he directed comments to Tom Gaziano of the Heritage Foundation, who had spoken against the Horn measure: "if the president vetoes it, he does so at his own peril... [you] take that statement back to the president."

Burton's commentary effectively muted the concerns of some Hill insiders, who feared that Republicans on the committee might bow to pressure from the White House and step back from supporting Horn's legislation. Although consideration of the president's bill to create a Department of Homeland Security delayed action on Horn's legislation for several months, the bill seems virtually assured of passing out of the House Committee as of this writing (August 2002). Unless the White House effectively prevents the measure from reaching the House floor, which remains a possibility despite Burton's threat, the Horn bill also should pass the House by a comfortable margin. Preliminary overtures also have been made to possible Senate sponsors by the coalition opposing 13223, but the bill's fate in the upper chamber appears less certain. Indeed, it remains extremely difficult to predict the final legislative outcome, though we remain optimistic and hopeful. Action in the courts, however, seems more predictable and perhaps even assured.

Executive order opponents opened their second front in the courts on November 28, 2001. Public Citizen, a Washington, D.C.-based nonprofit consumer advocacy organization, filed suit on that date in federal court 
to overturn the executive order on behalf of the American Historical Association, the Organization of American Historians, the National Security Archive, the Reporters Committee for Freedom of the Press, Public Citizen, and the eminent historians Hugh Graham and Stanley Kutler. The plaintiffs contended clearly and forcefully that the executive order violates the Presidential Records Act of 1978, as well as various provisions of the U.S. Constitution. They also asked the court to declare that the Archivist of the United States and the National Archives and Records Administration should not implement the order, and sought a permanent injunction against implementation. In the plaintiffs' view, Bush's executive order violates the letter as well as the spirit of the law. Joan Claybrook, president of Public Citizen, succinctly summarized the complainants" viewpoint: "We will not stand by while the administration tramples on the people's right to find out about their own government. The president should not have the ability to arbitrarily withhold

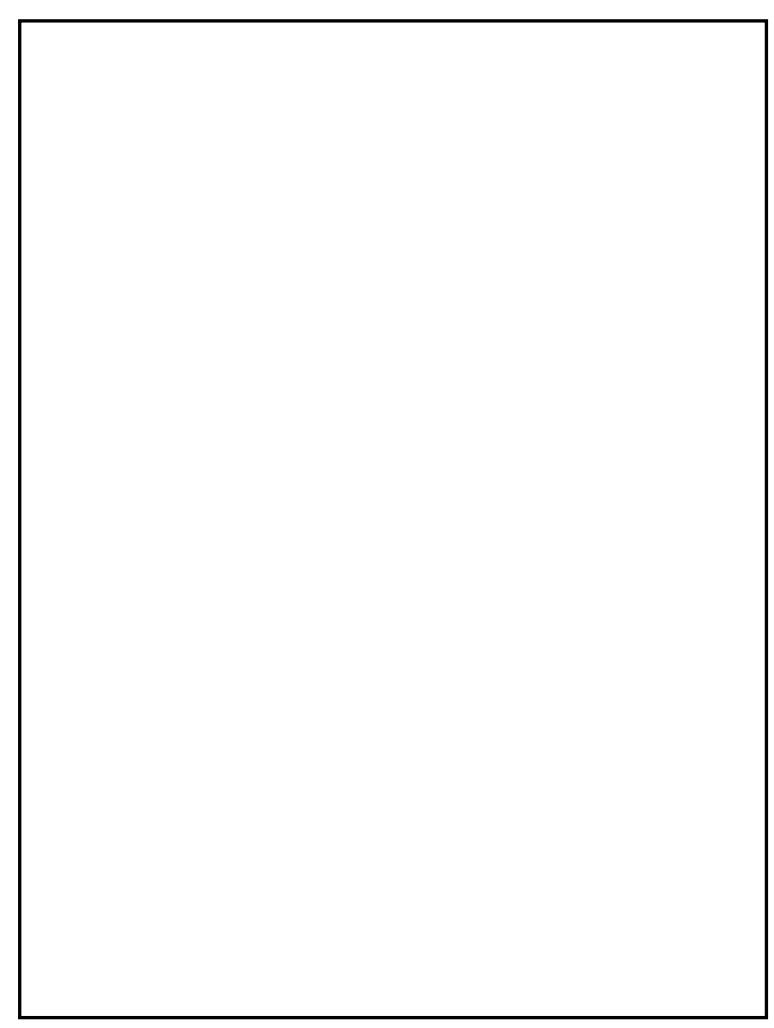


public information to hide wrongdoing or avoid embarrassment." This decision to pursue court action followed on the heels of a strategic meeting organized by the NCC on November 9, at which time the interested parties decided that legal action appeared necessary. ${ }^{8}$

The lawsuit already has produced some positive results. All of the Reagan records containing confidential advice to the president and vice president have been released. Operating under the pressure of a lawsuit, the White House could not indefinitely stall requests for access under the pretext that they needed to continue "reviewing" the documents. The White House did orchestrate several partial releases of Reagan documentation over the course of the past year, usually timed to coincide with key disposition points concerning the litigation. In late July 2002, however, the Justice Department informed lawyers at the Public Citizen Litigation Group that they finally authorized the release of the last of the contested 68,000 documents from Ronald Reagan's presidency. Our attorneys now believe that, with the release of the Reagan records, the government will argue that the lawsuit should be dismissed. Scott Nelson of Public Citizen asserted that "the White House desperately wants to avoid having a court decide whether its executive order is lawful. So it has made every effort to dodge the issues." The plaintiffs' broader concerns, however, have not disappeared. Nelson cogently and correctly observes that "the government is continuing to implement the executive order and is using it to hold up release of other documents, so the legal challenge to the order remains a live issue."

We remain extremely hopeful concerning victory in the courts, but all of us in the historical and archival community should remain vigilant in defending our right to access government documents. Unfortunately, Bush's executive order concerning the Presidential Records Act does not 
constitute the only challenge facing historians and archivists in the public records arena. For example, the Bush administration has created an interagency group that is charged with preparing changes to the Clinton administration's 1995 Executive Order 12958, which governs national security classification and declassification policy. Clinton's order provides that most classified records should be declassified automatically when they reach 25 years old, and his order has resulted in the release of millions upon millions of historical documents. Although the Bush administration claims that its proposed changes in this area will be "more of a refinement" than a major rewrite of Clinton's executive order, we need to greet such assertions with appropriate suspicion. After all, Executive Order 13233 had been presented by the Bush White House as being merely "procedural" in nature. And that perhaps constitutes the most significant lesson of this entire matter: the need for vigilance. Eternal vigilance. 